\title{
A Systematic Review of Antiamyloidogenic and Metal-Chelating Peptoids: Two Structural Motifs for the Treatment of Alzheimer's Disease
}

\author{
Sherri C. Young \\ Department of Chemistry, Muhlenberg College, 2400 Chew Street, Allentown, PA 18104, USA; \\ sherriyoung@muhlenberg.edu; Tel.: +1-484-664-3271
}

Received: 10 January 2018; Accepted: 30 January 2018; Published: 31 January 2018

\begin{abstract}
Alzheimer's disease (AD) is an incurable form of dementia affecting millions of people worldwide and costing billions of dollars in health care-related payments, making the discovery of a cure a top health, societal, and economic priority. Peptide-based drugs and immunotherapies targeting AD-associated beta-amyloid $(\mathrm{A} \beta)$ aggregation have been extensively explored; however, their therapeutic potential is limited by unfavorable pharmacokinetic (PK) properties. Peptoids ( $N$-substituted glycine oligomers) are a promising class of peptidomimetics with highly tunable secondary structures and enhanced stabilities and membrane permeabilities. In this review, the biological activities, structures, and physicochemical properties for several amyloid-targeting peptoids will be described. In addition, metal-chelating peptoids with the potential to treat AD will be discussed since there are connections between the dysregulation of certain metals and the amyloid pathway.
\end{abstract}

Keywords: Alzheimer's disease; peptoids; peptidomimetics; beta-amyloid aggregation; beta-amyloid aggregation inhibitors; pharmacokinetics; metal chelators

\section{Introduction}

Alzheimer's disease (AD) is an incurable form of dementia afflicting an estimated 5.5 million Americans [1]. By 2050, AD will affect an estimated 13.8 million patients [1] and cost the United States as much as $\$ 1.1$ trillion [2], representing a growing health, societal, and economic concern. Four of the five $\mathrm{AD}$ drugs currently on the market (donepezil, rivastigmine, galantamine, and a donepezil-memantine combination drug) inhibit the enzyme acetylcholinesterase (AChE) in order to mitigate cholinergic dysfunction and subsequent neurodegeneration and memory decline [3,4]. Memantine targets the $\mathrm{N}$-methyl-D-aspartate (NMDA) receptor, which, at increased levels, can lead to deterioration in cognitive function [5]. Since marketed AD drugs treat symptoms rather than the underlying disease pathology, there is a dire need for new AD drugs with different mechanisms of action.

From 2002 to 2012, 99.6\% of AD drugs that entered clinical trials failed, which is a higher rate of failure than either oncology or cardiovascular drugs [6,7]. Recent high-profile clinical trial failures have slowed progress toward a cure and cast doubt on one of the most widely studied hypotheses for AD pathology, the amyloid hypothesis [8,9]. Challenges surrounding AD drug discovery include mis-diagnosis of clinical trial patients [10-12], a lack of reliable biomarkers [10], and an incomplete understanding of the complex and multifaceted disease pathology involving tau hyper-phosphorylation, $\mathrm{A} \beta$ aggregation, cholinergic dysfunction, metal dysregulation, inflammation, and oxidative stress $[3,6,13,14]$, which are often interconnected. In addition, AD drugs must penetrate the blood-brain barrier (BBB), further limiting the number of viable therapeutic options [15].

In recent years, peptoids ( $N$-substituted glycine oligomers; [16]) have emerged as a promising class of peptidomimetics [17] with a range of properties, including anti-cancer [18] and antibacterial 
activities $[19,20]$. Peptoids have several advantages over peptides as drug candidates, including their ease of synthesis via either solid-phase synthesis (SPS; [16,21,22]) or solution-phase methods [23] and their nonimmunogenic nature [24]. Since peptoids are synthesized from primary amine building blocks, of which thousands are commercially available, tremendous side-chain diversity can be readily achieved [25], and their secondary structures are tunable [20]. Furthermore, compared to peptide-based drugs and other biologics, linear and / or cyclic peptoids have more favorable pharmacokinetic (PK) properties, such as longer biological half-lives, due to their unnatural structures, and higher membrane permeabilities, due to a limited number of hydrogen-bond donors (HBDs; Figure 1) [26-29]. Together, these properties make peptoids viable drug candidates for any disease, but especially for AD and other CNS diseases in which BBB permeability is critical to drug success.

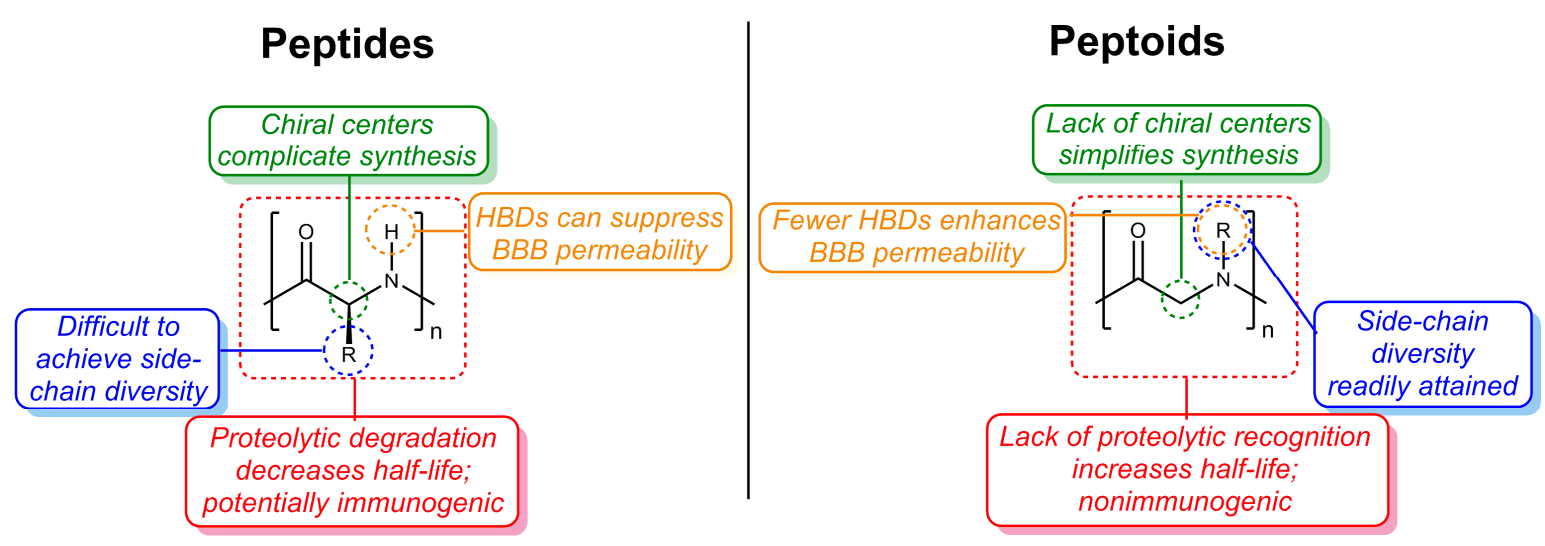

Figure 1. Summary of advantages of peptoids over peptides.

This review presents the structures, methods used, biological activities, and physicochemical properties for various antiamyloidogenic peptoids. In addition, several metal-chelating peptoids are presented that could prove useful against $\mathrm{AD}$, since there are connections between the dysregulation of certain metal ions and the amyloid pathway [6,30] (vide infra).

The medicinal properties of peptide and peptoid foldamers, including antibacterial properties and their abilities to disrupt protein-protein interactions, have been reviewed $[19,20]$. The potential of peptoids as $\mathrm{AD}$ diagnostic agents, including for the detection of $\mathrm{A} \beta_{1-42}$, has been reviewed by Kodadek and Vanderstichele [31] and will not be discussed here.

\section{Amyloid-Targeting Peptoids}

\subsection{Overview}

The amyloid hypothesis, first reported in 1984 [32,33], states that accumulation of A $\beta$ peptide (specifically the more neurotoxic $A \beta_{1-42}$ peptide) oligomers, aggregates, and fibrils plays a role in $\mathrm{AD}$ and can trigger a host of effects, including neuroinflammation, taupathy, and neuronal cell death [34]. This hypothesis has replaced the cholinergic hypothesis as the predominant foundation for the development of new AD therapies. Emerging evidence suggests soluble aggregates rather than fibrils are responsible for AD-associated neurotoxicity, which has led to a shift in approach in anti-amyloid drug design [35,36]. Although the importance of the amyloid hypothesis in AD drug discovery has been questioned [8,9], $\mathrm{A} \beta$, and its associated genes, proteins, and pathways, remains the most extensively studied and pursued AD target [34].

Several peptide-based drugs have been explored to target AD-associated $\mathrm{A} \beta$ aggregation [37]. Due to their low BBB penetrabilities, short half-lives, and low bioavailabilities, many of these compounds are not ideal clinical candidates. Unfortunately, in some cases, attempts to improve bioavailability and stability resulted in decreased inhibition of $A \beta$ aggregation [38]. Amyloid immunotherapies have 
shown promise, and some have reached clinical trials, but, to date, none have reached the market, in some cases due to adverse effects [39]. Immunotherapies do not penetrate the BBB due to their large size, polarity, and large number of HBDs and hydrogen-bond acceptors (HBAs), further limiting their therapeutic potential [15]. Considering the limitations of current amyloid-targeting therapies, peptoids, which have more favorable PK properties, represent a promising therapeutic class. Section 2 presents various antiamyloidogenic peptoids. Peptoid structures are presented in Figure 2, methods and reported biological activities are in Table 1 , and physicochemical properties are summarized in Table 2.

\subsection{Peptoid-Based $A \beta_{1-42}$-Aggregation Inhibitors}

Yang et al. recently discovered the nanomolar $A \beta_{1-42}$ inhibitor amyloid inhibitory peptoid 1 (AIP1; Figure 2). AIP1 increased the lag time to form the critical nucleus for fibril formation and demonstrated in vitro BBB permeability in line with that of previously reported $A \beta$-aggregation inhibitors (Table 1) [40]. In addition to providing a viable lead for $\mathrm{AD}$, this work presents an approach for the discovery of additional peptoid-based $A \beta_{1-42}$ aggregation inhibitors.

Bezprozvanny and coworkers reported monomer inhibitor of amyloid 1 (IAM1; Figure 2) that selectively suppressed $A \beta_{1-42}$ aggregation and could be used to detect $A \beta_{1-42}$ [41,42]. The authors also investigated the dimer (IAM1)2, which had an even higher $A \beta_{1-42}$ affinity than the monomer and demonstrated neuroprotective properties (Table 1). The peptoid building blocks in this study were chosen to increase structural diversity and water solubility yet allow for $A \beta_{1-42}$-peptoid interactions and suitable BBB penetrability.

\subsection{Peptoid-Based $A \beta_{1-40}$-Aggregation Inhibitors}

Servoss et al. designed peptoids to mimic residues $16-20$ of $A \beta_{1-40}$ (KLVFF) [43,44], the hydrophobic region responsible for aggregation [45,46]. One peptoid in particular, JPT1 (Figure 2), adopts a stable polyproline type-I (PPI)-like helical structure, which enhances interactions with $\mathrm{A} \beta$ and suppresses peptide aggregation through pi-pi stacking interactions between the peptoid and the phenylalanine residues of the $A \beta_{1-40}$ section. This peptoid suppressed $A \beta_{1-40}$ aggregation in a dose-dependent manner, decreased fibril formation, and decreased the lag time to form fibrils (Table 1). A follow-up study investigated the impact of side-chain chirality and placement on $A \beta_{1-40}$-aggregation suppression [47]. Interestingly, by removing the aromatic side chains or moving the chiral aromatic side chains, inhibition of $A \beta$ aggregation was still maintained; however, the morphology and size of the aggregates changed compared to the original JPT1 analog. The authors proposed that off-pathway aggregates were formed in order to surpass/suppress fibril formation. These studies have enhanced the understanding of $A \beta$-small molecule interactions and could allow for more effective design of new amyloid therapies. Although the BBB permeabilities of JPT1 and related analogs were not assessed, the lipophilic nature of these $A \beta$-aggregation inhibitors and the limited number of HBDs could result in suitable BBB permeabilities, although the molecular weights ( 1000 Da; Table 2$)$ are outside of the typical range for CNS drugs [48].

Kirshenbaum and Sadowski reported a large library of stable peptide/peptoid hybrids that suppress $A \beta_{1-40}$ fibrillization and oligomerization in vitro and in vivo and mitigate $A \beta$-mediated NMDA receptor loss (Table 1); these molecules could also be used in AD diagnosis [49]. The approach involved replacing specific amino acid residues of $A \beta_{1-42}$ (or sections thereof) with peptoids or other unnatural amino acids in order to improve PK properties. These peptoids have properties consistent with BBB-permeable molecules (hydrophobic nature, limited number of HBDs, and high plasma stability), making them viable therapeutic candidates. Furthermore, these molecules exhibited suitable BBB penetrabilities, as evidenced by detection in cerebrospinal fluid after intravenous (iv) administration [49]. 

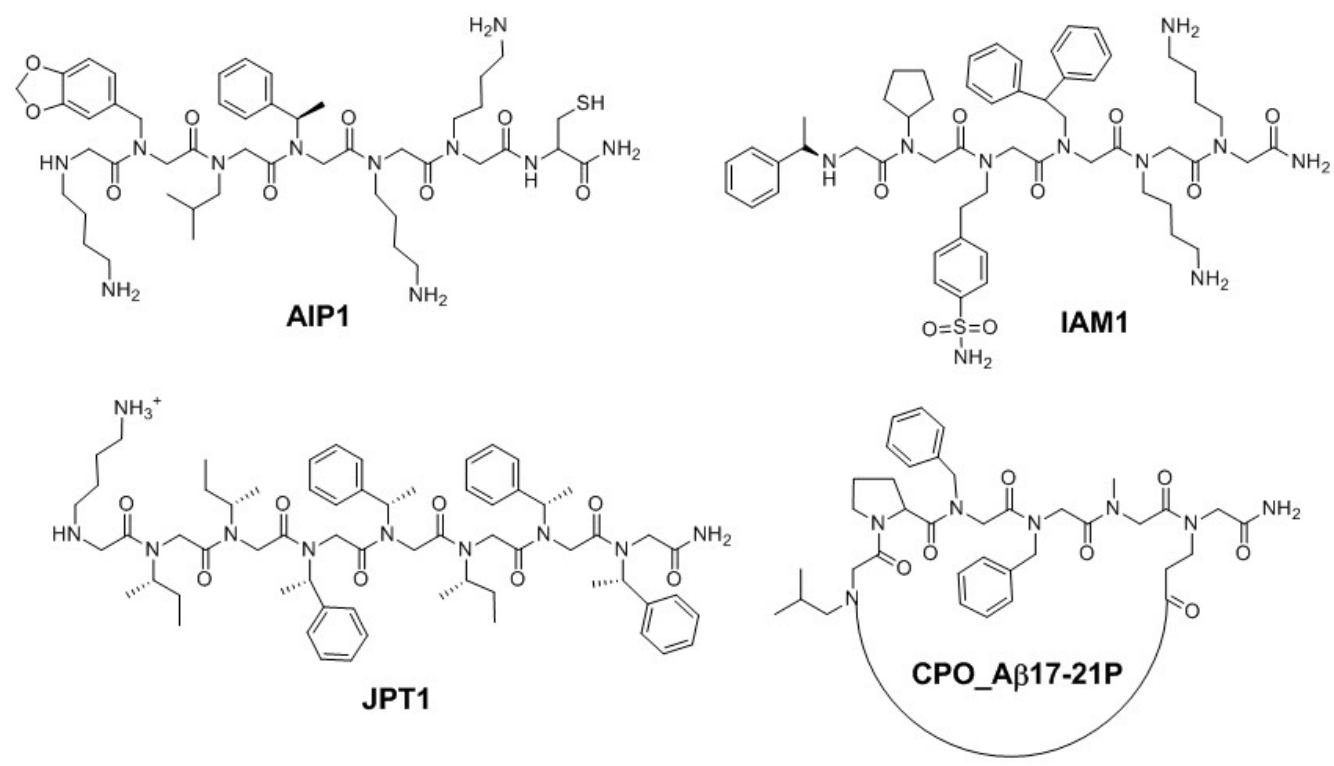

Figure 2. Structures of antiamyloidogenic peptoids AIP1 [40], IAM1 [41,42], JPT1 [43,44,47], and CPO_A $\beta 17-21 \mathrm{P}$ [50]. Protonation states are the same as those shown in the original references.

\subsection{Peptoids Targeting the Apolipoprotein E4-A $\beta$ Interaction}

Apolipoprotein E4 (apoE4), a protein that is a genetic risk factor in late-stage AD, plays a role in $\mathrm{A} \beta$ accumulation, plaque formation, and tau pathology. ApoE/apoE4 can interact with specific residues of $A \beta$ to promote aggregation; the apoE4 allele also decreases $A \beta$ brain clearance [34]. As such, the $\mathrm{A} \beta$-apoE interaction has been explored as a target for novel AD therapies. Kwon, Wisniewski, and coworkers discovered CPO_A $317-21 \mathrm{P}$ (Figure 2) from a small library of cyclic and linear peptoids; this peptoid inhibited apoE4-mediated $A \beta$ aggregation, had a favorable safety profile, improved cognitive function in a transgenic mouse model, and did not trigger a neuroinflammatory response (Table 1) [50]. Furthermore, the fairly low molecular weight ( 700 Da; Table 2), hydrophobicity, and cyclic nature of this compound $[27,28]$ could result in favorable PK properties. The BBB permeability of CPO_A $\beta 17-21 \mathrm{P}$ was not explicitly explored, although in vivo efficacy suggests suitable permeability [50].

\subsection{Comparative Structure-Activity Relationship for Amyloid-Targeting Peptoids}

The amyloid-targeting peptoids presented in Section 2 contain aromatic, hydrophobic, and aliphatic residues to facilitate interactions with $A \beta_{1-40 / 42}$ and/or to improve BBB penetrability [40,42]. In addition, some of these peptoids contain hydrophilic residues (e.g., Nlys, a lysine-based peptoid residue) to promote water solubility and chiral residues, in particular chiral aromatic residues (e.g., $N-(S)-1$-phenylethylglycine (Nspe)), to promote helicity [44,47].

$A \beta_{1-42}$ aggregation inhibition could be achieved by binding to the $N$-terminus of $A \beta_{1-42}$ [40], binding to the hydrophobic $\beta$-turn- $\beta$-sheet region (residues 18-42) of the peptide, or interactions with the C-terminus [42]. Bezprozvanny et al. proposed that the $A \beta_{1-42}$ selectivity of IAM1 was due to interactions between the hydrophobic isoleucine and alanine residues at the $\mathrm{C}$-terminus of the peptide, potentially due to the increased rigidity of this region of $A \beta_{1-42}$ compared to $A \beta_{1-40}[42,51]$. According to docking studies, the $A \beta_{1-42}$-binding activity of AIP1 could be due to $\pi-\pi$ stacking and hydrogen-bonding interactions between the peptoid and $A \beta_{1-42}$ and the peptoid binds to the $\mathrm{N}$-terminus of $A \beta_{1-42}[40]$. 
Modulation of $A \beta_{1-40}$ aggregation can occur through $\pi-\pi$ stacking interactions between the KLVFF portion of the peptide and aromatic peptoid residues, which may be responsible for the activity of JPT1 [44,47]. Since JPT1 was not assessed as an $A \beta_{1-42}$ inhibitor, it is unclear whether the peptoid would exhibit $A \beta_{1-40}$-selectivity or dual inhibition. The amyloid-targeting peptoids herein exhibit a range of structures, selectivities, and activities to expand the arsenal of potential AD drugs.

Table 1. Methods used and bioactivities reported for example antiamyloidogenic peptoids.

\begin{tabular}{|c|c|c|c|}
\hline Name/Description & Methods Used & Bioactivities & References \\
\hline IAM1 and (IAM1)2 & $\begin{array}{l}\text { SPS used to generate an on-bead library containing over } \\
38,000 \text { peptoid analogs; bead-based screening methods, a } \\
\text { ThT assay, and an amyloid toxicity assay used to test for } \\
\text { A } \beta_{1-42 \text {-aggregation inhibitory activities. }}\end{array}$ & $\begin{array}{l}\text { The } A \beta_{1-42} \text { binding affinities for } \\
\text { IAM } 1 \text { and (IAM1) } 2 \text { are } 0.43 \pm 0.05 \\
\text { and } 0.06 \pm 0.04 \mu \mathrm{M} \text {, respectively. } \\
\text { IAM1 has higher } \mathrm{A} \beta_{1-42}: \mathrm{A} \beta_{1-40} \\
\text { selectivity ( } 9.6 \text {-fold vs. } 2.1 \text {-fold); } \\
\text { (IAM1)2 restored viability of } \\
\text { neurons to } 87 \% \text { at } 100 \mathrm{nM} \text {. }\end{array}$ & {$[41,42]$} \\
\hline JPT1 & $\begin{array}{l}\text { ThT fluorescence and dot blot analyses used to test } \\
\text { antiamyloidogenic properties; fibril morphology } \\
\text { investigated using transmission electron microscopy } \\
\text { (TEM) and Nile Red spectroscopy; peptoid helicity } \\
\text { investigated via CD spectroscopy. }\end{array}$ & $\begin{array}{l}\text { Dose-dependent inhibition of } \\
\mathrm{A} \beta_{1-40} \text { aggregation was reported } \\
(81.2 \pm 4.4 \% \text { at } 100 \mu \mathrm{M} \text { of JPT } 1) ; \\
\text { fewer } \mathrm{A} \beta \text { fibrils were formed and } \\
\text { the lag time was decreased. }\end{array}$ & {$[43,44,47]$} \\
\hline $\begin{array}{l}\text { Peptoid/peptide } \\
\text { hybrids }\end{array}$ & $\begin{array}{l}\text { MTT assay, a ThT aggregation assay, and an } \\
\text { oligomerization assay used to assess impact on } A \beta_{1-40} \\
\text { oligomerization. }\end{array}$ & $\begin{array}{l}\text { Hybrids suppress } A \beta \\
\text { oligomerization; one analog } \\
\text { reduced the amount of } A \beta_{1-40} \\
\text { oligomers by } 61.3 \% \text {. }\end{array}$ & [49] \\
\hline CPO_A $\beta 17-21 \mathrm{P}$ & $\begin{array}{l}\text { Linear and cyclic peptoid library synthesized via SPS; SPR, } \\
\text { a ThT assay, 3-(4,5-dimethylthiazol-2-yl)-5-(3- } \\
\text { carboxymethoxyphenyl)-2-(4-sulfophenyl)- } 2 \text { H-tetrazolium) } \\
\text { (MTS) cell viability assay, behavioral testing, } \\
\text { immunohistochemistry, western blot, and ELISA used to } \\
\text { study binding to apoE4-A } \beta \text {. }\end{array}$ & $\begin{array}{l}\text { ApoE4-A } \beta \text { binding inhibited with } \\
\text { a half-maximal inhibitory } \\
\text { concentration }\left(\mathrm{IC}_{50}\right) \text { of } 1.02 \mathrm{nM} \text {; } \\
\text { transgenic mice exhibited } \\
\text { significant cognitive improvement. }\end{array}$ & {$[50]$} \\
\hline
\end{tabular}

Table 2. Physicochemical properties for example antiamyloidogenic peptoids.

\begin{tabular}{ccccc}
\hline Name & Molecular Weight (Da) & HBDs & HBAs $^{\mathbf{1}}$ & References \\
\hline AIP1 & 970.25 & 10 & 20 & {$[40]$} \\
IAM1 & 1037.34 & 9 & 18 & {$[41,42]$} \\
(IAM1)2 & $2368.30^{2}$ & 20 & 42 & {$[41,42]$} \\
JPT1 & 1130.51 & 6 & 18 & {$[43,44,47]$} \\
CPO_A $\beta 17-21 P$ & $703.37^{3}$ & 2 & 14 & {$[50]$} \\
\hline
\end{tabular}

${ }^{1}$ To determine the number of HBAs, Lipinski's criteria for hydrogen-bond accepting capacity are estimated by adding up the number of nitrogen and oxygen atoms in the molecule [52]; ${ }^{2}$ Calculated mass reported in original reference; ${ }^{3}$ Exact mass reported in original reference. 


\section{Metal-Chelating Peptoids}

\subsection{Connections between Metal Dysregulation, the Amyloid Pathway, and AD Pathology}

The dysregulation of $\mathrm{Fe}, \mathrm{Cu}$, and $\mathrm{Zn}$ plays a documented role in $\mathrm{AD}$, and this dysregulation could be linked to other AD pathologies, including A $\beta$ aggregation and tau hyperphosphorylation [6]. Amyloid plaques contain abnormally high levels of these three metals, and $\mathrm{Cu}$-amyloid complexes have been linked to reactive oxygen species (ROS) generation, mitochondrial dysfunction, and neuronal cell death [6]. In addition, Fe-amyloid complexes can trigger oxidative stress, and an imbalance of all three metal ions can interfere with $\mathrm{A} \beta$ degradation [30]. Despite the role of these metals in AD, metal chelators are rarely explored as AD therapies. In addition to addressing metal dysregulation, these drugs could feasibly mediate AD-associated A $\beta$ aggregation, ROS generation, inflammation, and oxidative stress. Developing a relatively nontoxic drug that is selective for the metal ions of interest, can extract metal ions from amyloid plaques, and can penetrate the BBB is a formidable challenge [6]. In Section 3, various metal-chelating peptoids are presented, with a focus on peptoids that bind to AD-associated metals. The structures of these peptoids are presented in Figure 3, methods used and reported biological activities are in Table 3, and physicochemical properties are summarized in Table 4.

\subsection{Cu(II)-Binding Peptoids}

Maayan and coworkers have rationally designed and synthesized multiple classes of metal-binding peptoids, including (1) Cu(II)-binding peptoids with 2-(1H-1,2,3-triazol-4-yl)pyridine and 2-(1H-1,2,3-triazol-1-ylmethyl)-pyridine side chains as well as Nspe groups to promote helicity [53]; (2) peptoid 3-, 4-, and 5-mers containing terpyridine, phenathroline, and hydroxyquinoline side chains [54]; and (3) $\mathrm{Cu}(\mathrm{II})$ - and $\mathrm{Co}(\mathrm{II})$-binding peptoids with 8-hydroxy-2-quinolinemethyl (HQ) groups for metal binding and hydrophilic (S)-1-methoxy-2-propylamine (Nsmp) groups to induce chirality and promote water solubility (Table 3) [55]. Other HQ-containing peptoids were developed to bind $\mathrm{Cu}$ (II) and $\mathrm{Co}$ (II) [56], and a follow-up study revealed the stabilizing effect of $\mathrm{Cu}$ (II) coordination on PP-I-like peptoid helices and the role of peptoid sequence and geometry in folding behavior [57].

Of particular interest are the selective $\mathrm{Cu}$ (II)-binding peptoids since this metal plays an important role in AD [6]. For example, helix HQT $i+3$ (Figure 3) binds $\mathrm{Cu}$ (II) selectively when in a mixture of other metal ions such as $\mathrm{Zn}$ (II), Fe(III), Co(II), Ni(II), and Mn(II) [58]. This peptoid can also simultaneously bind two different metal ions, such as $\mathrm{Cu}$ and $\mathrm{Zn}$, further enhancing the abilities of these molecules to mimic the complex processes of a natural protein. Metal-binding studies revealed that the selectivity and cooperativity are from a combination of helicity and pre-organization of the ligands. The peptoid could also adjust its binding mode (intramolecular vs intermolecular) in response to changes in metal ion concentrations, for example [58].

Varma and coworkers reported a calix[4]arene peptoid tetramer that binds $\mathrm{Cu}(\mathrm{II})$ selectively in the presence of various other metal cations (as perchlorates), including $\mathrm{Cr}$ (III), $\mathrm{Mn}$ (II), Fe(II), Co(II), $\mathrm{Cu}(\mathrm{II}), \mathrm{Zn}(\mathrm{II}), \mathrm{Hg}(\mathrm{II}), \mathrm{Ag}(\mathrm{I}), \mathrm{Pb}(\mathrm{II}), \mathrm{Cd}(\mathrm{II}), \mathrm{Na}, \mathrm{K}, \mathrm{Ca}$, and Al(III) (Table 3; Figure 3) [59]. One of the peptoids was reported to have high selectivity for $\mathrm{Cu}(\mathrm{II})$ based on no change in the observed UV band in the presence of other metal ions. The numbers of HBDs and HBAs as well as the molecular weights of these calix[4]arene derivatives, which range from 1600 to $2000 \mathrm{Da}$, could limit the potential of these molecules as CNS drugs (Table 4). 
Table 3. Methods used and bioactivities reported for example metal-chelating peptoids.

\begin{tabular}{|c|c|c|c|}
\hline Name/Description & Methods Used & Bioactivities & References \\
\hline $\begin{array}{l}\text { 6-PyrT2 and other } \\
\text { Cu(II)-binding peptoids }\end{array}$ & $\begin{array}{l}\text { Peptoids synthesized via } \\
\text { microwave-accelerated solid-phase click } \\
\text { chemistry; CD spectroscopy and } \\
\text { isothermal titration calorimetry (ITC) } \\
\text { used to investigate peptoid-Cu(II) } \\
\text { binding. }\end{array}$ & $\begin{array}{l}\text { Association constants }\left(K_{\mathrm{A}}\right) \text { for } \\
6 \text {-PyrT2-Cu(II) complex are } \\
3.318 \times 10^{6} \text { in methanol and } \\
3.071 \times 10^{6} \text { in acetonitrile. }\end{array}$ & [53] \\
\hline $\begin{array}{l}\text { Nme-Npm-Netp-Npm-Nme } \\
\text { and other } \\
\text { heterocyclic-amine- based } \\
\text { peptoids }\end{array}$ & $\begin{array}{l}\text { Peptoid 3-, 4-, and 5-mers containing } \\
\text { metal-chelating terpyridine, } \\
\text { phenathroline, and HQ side chains } \\
\text { synthesized via SPS. }\end{array}$ & $\begin{array}{l}\text { Metal-binding properties were } \\
\text { not explored. }\end{array}$ & [54] \\
\hline $\begin{array}{l}\text { 7mer-HQ2 and other } \\
\mathrm{Cu}(\mathrm{II})-\text { and } \mathrm{Co}(\mathrm{II}) \text {-binding } \\
\text { peptoids }\end{array}$ & $\begin{array}{l}\text { Peptoids synthesized via SPS; near-UV } \\
\text { CD spectroscopy, UV titration, and EPR } \\
\text { used to investigate peptoid-metal } \\
\text { binding. }\end{array}$ & $\begin{array}{l}\text { 7mer-HQ2 formed a 1:1 } \\
\text { complex with } \mathrm{Cu}(\mathrm{II}) \text {. }\end{array}$ & [55] \\
\hline $\begin{array}{l}\text { Helix HQT } i+3 \text { and other } \\
\text { selective } \mathrm{Cu}(\mathrm{II}) \text {-binding } \\
\text { peptoids }\end{array}$ & $\begin{array}{l}\text { Peptoids synthesized via SPS; } \\
\text { metal-binding properties studied using } \\
\text { UV titration, CD spectroscopy, electron } \\
\text { paramagnetic resonance (EPR), and } \\
\text { inductively coupled plasma mass } \\
\text { spectrometry (ICP-MS) experiments. }\end{array}$ & $\begin{array}{l}K \text { for formation of peptoid-Cu } \\
\text { complex is } 1.03 \pm 0.49 \times 10^{13} \\
\mathrm{M}^{-1} ; \mathrm{Cu}(\mathrm{II}) \text { selectivity } \\
\text { observed in the presence of } \\
\text { over } 800 \times \text { and } 670 \times \text { higher } \\
\text { concentrations of } \mathrm{Mn}(\mathrm{II}) \text { and } \\
\mathrm{Ni}(\mathrm{II}) \text {, respectively. }\end{array}$ & [58] \\
\hline $\begin{array}{l}\text { Selective-Cu(II)- binding } \\
\text { calix }[4] \text { arene peptoid } \\
\text { tetramers }\end{array}$ & $\begin{array}{l}\text { Peptoids synthesized using an } \\
\text { isocyanide based multi-component } \\
\text { reaction (MCR); UV-vis titration used to } \\
\text { investigate metal binding. }\end{array}$ & $\begin{array}{l}\text { One of the peptoids binds to } \\
\mathrm{Cu}(\mathrm{II}) \text { selectively in the } \\
\text { presence of various metal } \\
\text { cations (as perchlorates). }\end{array}$ & [59] \\
\hline $\begin{array}{l}\text { Selective and tight } \\
\text { Zn(II)-binding peptoids }\end{array}$ & $\begin{array}{l}\text { Peptoids synthesized via automated } \\
\text { SPS; ethylene glycol bis(2-aminoethyl } \\
\text { ether)- } N, N, N, N \text {-tetraacetic acid (EGTA) } \\
\text { competition assay, Förster resonance } \\
\text { energy transfer (FRET), CD } \\
\text { spectroscopy, and UV-vis spectroscopy } \\
\text { used to investigate metal binding. }\end{array}$ & $\begin{array}{l}\text { Some peptoids exhibited } \\
\text { Zn-binding affinity at least one } \\
\text { order of magnitude higher } \\
\text { than that of various metal ions. }\end{array}$ & [60] \\
\hline $\begin{array}{l}\text { Benzyloxyethyl-based } \\
\text { peptoids free and } \\
\text { immobilized on a chitosan } \\
\text { film with antioxidant and } \\
\text { Fe-chelating properties }\end{array}$ & $\begin{array}{l}\text { 2,2-Diphenyl-1-picrylhydrazyl (DPPH) } \\
\text { and hydroxyl radical procedures were } \\
\text { used to assess antioxidant activities; } \\
\text { Fe-chelating properties investigated } \\
\text { using an EDTA-competition assay. }\end{array}$ & $\begin{array}{l}\text { Two of the free peptoids } \\
\text { exhibited concentration- } \\
\text { dependent radical scavenging } \\
\text { effect of up to } 80 \% \text { at } 5 \mathrm{~g} / \mathrm{L} \text {. }\end{array}$ & [61] \\
\hline $\begin{array}{l}\text { Screening for selective } \\
\mathrm{Ni}(\mathrm{II}) \text {-binding peptoids }\end{array}$ & $\begin{array}{l}\text { SPS used to synthesize peptoids; } \\
\text { high-throughput, bench-top X-ray } \\
\text { fluorescence screening (with ICP-MS } \\
\text { and a colorimetric assay for validation) } \\
\text { used to screen peptoids for } \\
\mathrm{Ni(II)-binding.}\end{array}$ & $\begin{array}{l}\text { Two of the peptoids bind } \mathrm{Ni}(\mathrm{II}) \\
\text { in the presence of other metal } \\
\text { ions. }\end{array}$ & [62] \\
\hline $\begin{array}{l}\text { Screening for iron- and } \\
\text { copper-binding peptoids }\end{array}$ & $\begin{array}{l}\text { Split-pool SPS used to synthesize } \\
\text { peptoid library; }{ }^{19} \mathrm{~F} \text { NMR spectroscopy } \\
\text { used to screen for metal-binding } \\
\text { properties. Results were validated } \\
\text { using UV titration. }\end{array}$ & $\begin{array}{l}\text { A } 12 \text { nmol detection limit was } \\
\text { achieved using a conventional } \\
\text { NMR spectrometer; } K_{\mathrm{D}} \text { values } \\
\text { of } \sim 27-44 \text { mM measured. }\end{array}$ & {$[63,64]$} \\
\hline
\end{tabular}




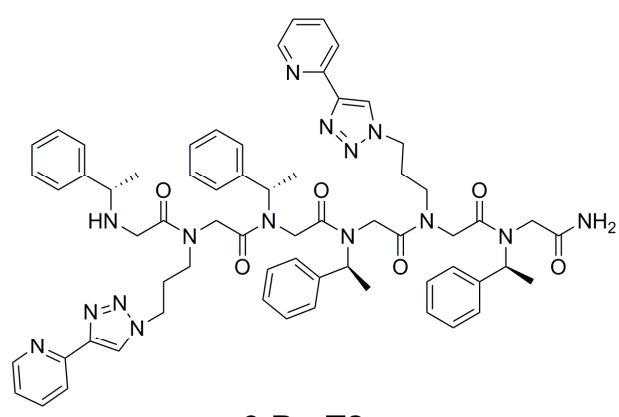

6-PyrT2

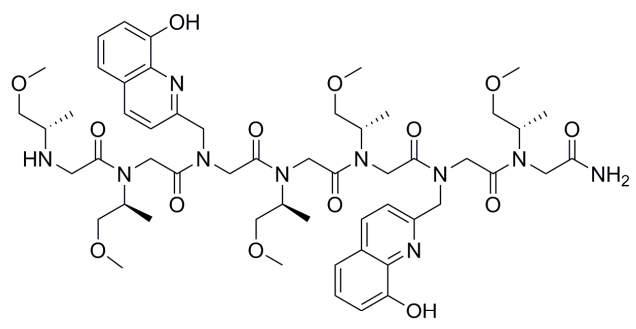

7mer-HQ2

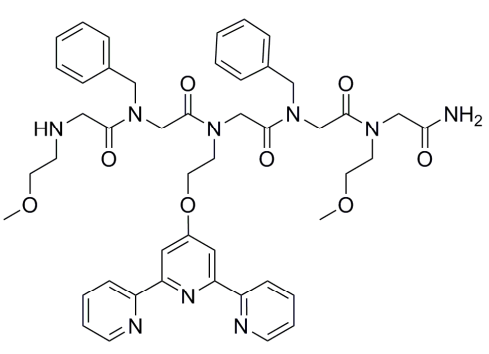

Nme-Npm-Netp-Npm-Nme

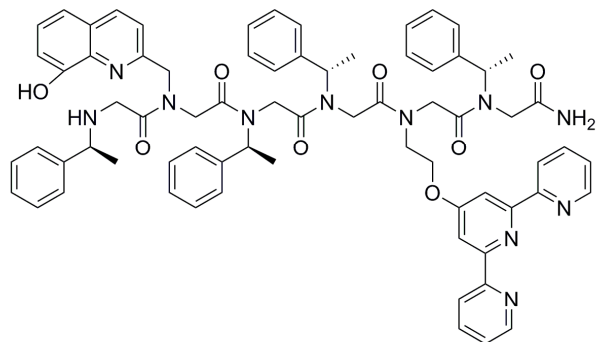

Helix HQT $i+3$

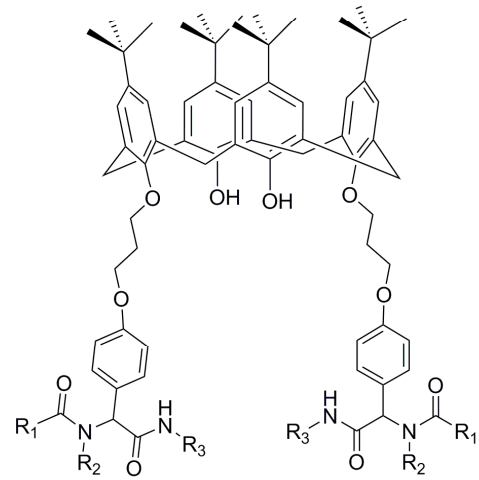<smiles>NC(=O)CN(Cc1ccncc1)C(=O)CN(CCC(=O)O)CC(=O)N(Cc1ccncc1)C(=O)N(CC(=O)O)CC(=O)NCc1ccc(I)cc1</smiles>

\section{PentA}

\section{calix[4]arene-based}

peptoid

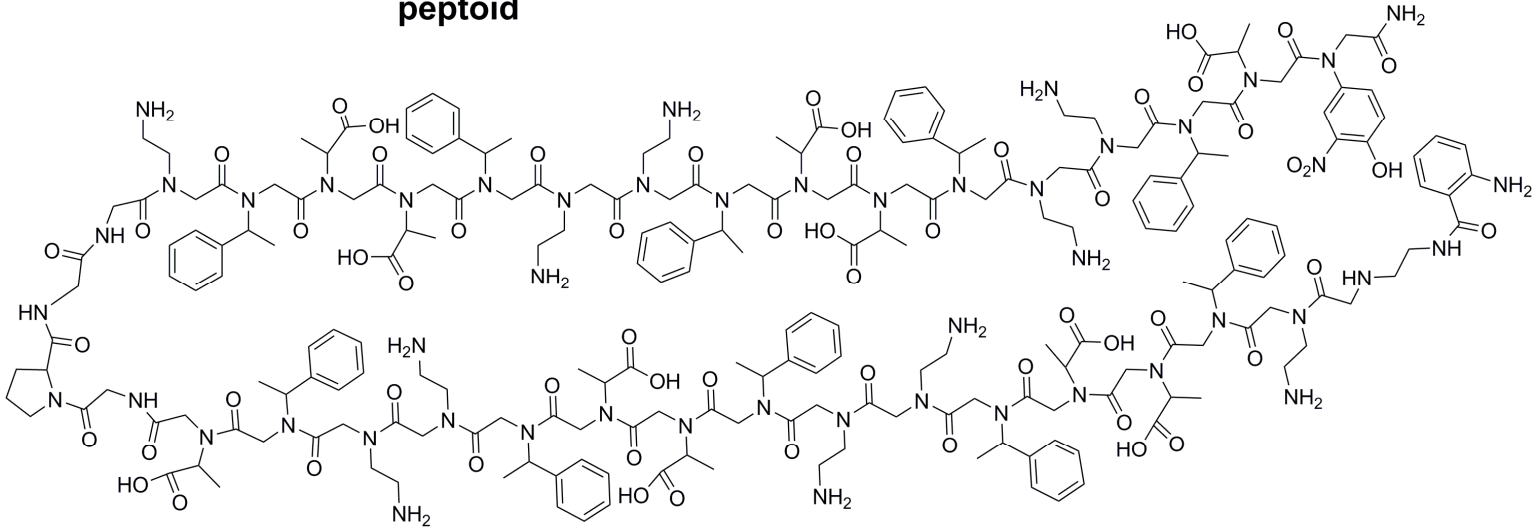

\section{Example $\mathrm{Zn}$-binding peptoid}

Figure 3. Structures of metal-chelating peptoids 6-PyrT2 [53], Nme-Npm-Netp-Npm-Nme [54], 7mer-HQ2 [55], Helix HQT $i+3$ [58], a calix[4]arene-based peptoid [59], a Zn(II)-binding peptoid [60], and pentA [62]. Protonation states are the same as those shown in the original references. 
Table 4. Physicochemical properties for example metal-chelating peptoids.

\begin{tabular}{ccccc}
\hline Name & $\begin{array}{c}\text { Molecular Weight } \\
\mathbf{( D a )}\end{array}$ & HBDs & HBAs ${ }^{\mathbf{1}}$ & References \\
\hline 6-PyrT2 & 1148.39 & 3 & 21 & {$[53]$} \\
Nme-Npm-Netp-Npm-Nme & 874.01 & 3 & 17 & {$[54]$} \\
7mer-HQ2 & 1091.27 & 5 & 24 & {$[55]$} \\
Helix HQT $i+3$ & 1208.43 & 4 & 19 & {$[58]$} \\
Calix[4]arene-based peptoids & $1613.94-1978.15^{2}$ & $4-6$ & $14-18$ & {$[59]$} \\
Zn(II)-binding peptoids & $4267.8-4681.2^{2}$ & $\sim 36-40$ & $\sim 89-93$ & {$[60]$} \\
Benzyloxyethyl-based peptoids & $414.22-512.29$ & $1-2$ & $7-8$ & {$[61]$} \\
PentA (Ni(II)-binding peptoid) & $844.2^{3}$ & 3 & 17 & {$[62]$} \\
\hline
\end{tabular}

${ }^{1}$ To determine the number of HBAs, Lipinski's criteria for hydrogen-bond accepting capacity are estimated by adding up the number of nitrogen and oxygen atoms in the molecule [52]; ${ }^{2}$ Range of $[\mathrm{M}+1]$ values reported in original reference; ${ }^{3}$ Calculated $\mathrm{m} / \mathrm{z}$ reported in original reference.

\subsection{Zn(II)-Binding Peptoids}

Zuckermann and coworkers designed heat-resistant two-helix bundles for tight $\mathrm{Zn}$ binding to mimic nature [60]. In the presence of the metal ions $\mathrm{Mg}(\mathrm{II}), \mathrm{Mn}(\mathrm{II}), \mathrm{Ca}(\mathrm{II}), \mathrm{Ni}(\mathrm{II}), \mathrm{Co}(\mathrm{II}), \mathrm{Cu}(\mathrm{II})$, and $\mathrm{Cd}(\mathrm{II})$, one of the peptoids exhibited a $\mathrm{Zn}$ (II)-binding affinity at least one order of magnitude higher than that of the other metal ions. The $\mathrm{Zn}$ affinities for some of the peptoids reported approach that of a Zn-binding protein [60]. This work provides a platform for future screening of peptoid-based metal-binders. The molecular weights $(>4000 \mathrm{Da})$, hydrophilicities, and number of HBDs of these molecules could preclude BBB penetrability, however (Table 4).

\subsection{Fe(II)-Binding Peptoids}

Taillefumier and coworkers reported a series of free and chitosan-bound benzyloxyethyl-based peptoids with both antioxidant and iron-chelating properties for use in food products [61]. Interestingly, binding the peptoids to the chitosan surface resulted in an enhancement of the antioxidant activity of the chitosan itself, although the free peptoids also exhibited some antioxidant properties (Table 3; [61]). Considering the predominant medical use of chitosan films as implants $[65,66]$, the unbound peptoids reported in this study will likely be more useful for AD therapy.

\subsection{Screening Approaches for the Discovery of Metal-Binding Peptoids}

With the capabilities to rapidly generate large compound libraries, high-throughput screening methods to search for peptoids with biologically relevant activities, including metal-binding capabilities, are essential for the discovery of peptoid-based therapies. Kirshenbaum et al. recently reported a bench-top X-ray fluorescence method to screen for metal-binding properties [62], which was validated using a colorimetric assay and ICP-MS. Using this assay, the detection of emission lines can determine metal-binding events. This method requires very small sample sizes and has pmol detection limits, making it an excellent candidate for on-bead analysis of peptoids generated via SPS. Furthermore, the analysis time is on the order of seconds, making this a high-throughput technology. The side chains of these peptoids mimicked histidine, glutamic acid, serine, tyrosine, and tryptophan residues to allow for metal binding, with some non-natural side chains, including pyridylalanine. Metal binding depended on the sequence and structure of the peptoid [62]. Although the authors specifically used this technology to screen for selective $\mathrm{Ni}$ (II)-binding peptoids, this approach could be used to search for peptoids that bind metal ions more prominently linked to AD pathology, viz $\mathrm{Cu}, \mathrm{Fe}$, and $\mathrm{Zn}$.

${ }^{19} \mathrm{~F}$ NMR spectroscopy, with aryl fluorides as tags, was used to screen a library of 90 peptoids for Fe- and Cu-binding properties [63,64]. Primary amines containing hydroxyl, imidazole, and carboxyl groups were used as building blocks to attempt to mimic the active site of serine proteases [64]. The metal-binding properties of hits were further investigated using UV-vis titration (Table 3). Selective 
$\mathrm{Cu}(\mathrm{II})$ - and $\mathrm{Fe}(\mathrm{III})$-binding peptoids, some with $K_{\mathrm{D}}$ values in the micromolar range, were discovered from this screening [64]. Advantages of this approach include the wide availability of the instrumentation and the high sensitivity and large chemical shift dispersion of ${ }^{19} \mathrm{~F}$ NMR spectroscopy.

\subsection{Comparative Structure-Activity Relationship for Metal-Chelating Peptoids}

As shown in Figure 3, common peptoid ligands for coordination to metals such as Fe and $\mathrm{Cu}$ include HQ (e.g., 7mer-HQ2), terpyridine (e.g., Helix HQT $i+3$ ), and pyridine derivatives (e.g., PentA) as well as residues to mimic natural amino acids such as histidine or serine, with HQ ligands being the most prevalent among the $\mathrm{Cu}$-binders $[55,58]$. In addition, chiral aromatic and aliphatic residues were often incorporated to induce helicity, an important property linked to the selectivities observed for some of the metal-binders. Hydrophilic Nsmp groups also promoted water solubility, which could result in more favorable PK properties.

\subsection{Advantages of Metal-Chelating Peptoids}

Many of these peptoids selectively chelate metals and have modifiable secondary structures and PK properties, thereby expanding their therapeutic potential. Furthermore, the ease of peptoid synthesis via the submonomer approach [16,21,22], the tremendous structural diversity possible, and the water solubilities of some of these peptoids, including Maayan's Nsmp-containing peptoids [55], provide additional advantages. In order to explore the full potential of these molecules as AD therapeutics, their stabilities and BBB penetrabilities should be explored. The metal-chelating peptoids herein have a reasonable balance of hydrophobic and hydrophilic groups; large molecular weights and large numbers of HBDs and HBAs could limit the potential of some of these molecules as CNS drugs (Table 4). Ultimately, the expanded knowledge of peptoid sequence-structure-function relationships will allow for more effective design of peptoid-based metal-chelators for specific applications, such as for the treatment of AD.

\section{Conclusions}

Several important advances have been made in the field of therapeutic peptoids. Peptoid-based

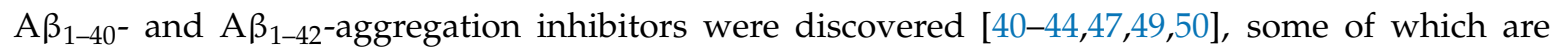
selective and/or BBB permeable [40-42]. Various selective metal-chelating peptoids, including those that bind AD-relevant metal ions, have been reported [53-55,58,59], and novel screening approaches will allow for the discovery of additional metal-binding peptoids [62-64]. In some cases, the metal-binding and peptoid-folding behavior can be controlled based on structure and sequence, thereby approaching the elegance of nature [60]. Based on the connections between $A \beta$ aggregation, AD pathology, and metal dysregulation [6], these molecules represent a promising future direction. Not only do the peptoids presented herein have a range of biological activities relevant to $\mathrm{AD}$, they have the potential to solve many of the PK issues surrounding traditional peptide-based therapeutics [26-29].

Considering the complex and polyetiological nature of AD, the one-target one-drug paradigm seems insufficient [67], and multifunctional drugs hold promise. Since tremendous structural diversity can be achieved with peptoids, these molecules can be readily modified to incorporate multiple functionalities. For example, a metal-chelating group could be incorporated into an A $\beta$-aggregation inhibitor, further expanding the potential of peptoid-based AD drugs.

Out of the 105 potential AD drugs currently in the pipeline [68], none of them are peptoids. With additional advances in the field of peptoids, this should soon change. The biggest hurdles that lie ahead include establishing full PK and in vivo activity profiles, including brain bioavailabilities, for AD-targeting peptoids, continuing to explore the impact of peptoid structure on biological function, and further studying the impact of peptoid sequence on secondary and tertiary structures $[69,70]$. As the field of biomimetic foldamers continues to advance [71], so will peptoid-based drug design. 
Acknowledgments: The author thanks the Muhlenberg College Department of Chemistry and the Office of the Provost for providing funds to publish in open access and for continual research support. The author also thanks James Devery at the University of Chicago Loyola for his constructive feedback on this manuscript.

Conflicts of Interest: The author declares no conflict of interest.

\section{References}

1. Hebert, L.E.; Weuve, J.; Scherr, P.A.; Evans, D.A. Alzheimer disease in the United States (2010-2050) estimated using the 2010 census. Neurology 2013, 80, 1778-1783. [CrossRef] [PubMed]

2. Alzheimer's Association. 2017 Alzheimer's disease facts and figures. Alzheimer's Dement. 2017, 13, 325-373. [CrossRef]

3. Bartus, R.T.; Dean, R.L.; Beer, B.; Lippa, A.S. The cholinergic hypothesis of geriatric memory dysfunction. Science 1982, 217, 408-414. [CrossRef] [PubMed]

4. Wilkinson, D.G.; Francis, P.T.; Schwam, E.; Payne-Parrish, J. Cholinesterase inhibitors used in the treatment of Alzheimer's disease: The relationship between pharmacological effects and clinical efficacy. Drugs Aging 2004, 21, 453-478. [CrossRef] [PubMed]

5. Newcomer, J.W.; Farber, N.B.; Olney, J.W. NMDA receptor function, memory, and brain aging. Dialogues Clin. Neurosci. 2000, 2, 219-232. [PubMed]

6. Robert, A.; Liu, Y.; Nguyen, M.; Meunier, B. Regulation of Copper and Iron Homeostasis by Metal Chelators: A Possible Chemotherapy for Alzheimer's Disease. Acc. Chem. Res. 2015, 48, 1332-1339. [CrossRef] [PubMed]

7. Cummings, J.L.; Morstorf, T.; Zhong, K. Alzheimer's disease drug-development pipeline: Few candidates, frequent failures. Alzheimers Res. Ther. 2014, 6, 37. [CrossRef] [PubMed]

8. Herrup, K. The case for rejecting the amyloid cascade hypothesis. Nat. Neurosci. 2015, 18, 794-799. [CrossRef] [PubMed]

9. Morris, G.P.; Clark, I.A.; Vissel, B. Inconsistencies and controversies surrounding the amyloid hypothesis of Alzheimer's disease. Acta Neuropathol. Commun. 2014, 2, 135. [CrossRef] [PubMed]

10. Weiner, M.W.; Veitch, D.P.; Aisen, P.S.; Beckett, L.A.; Cairns, N.J.; Green, R.C.; Harvey, D.; Jack, C.R.; Jagust, W.; Morris, J.C.; et al. The Alzheimer's Disease Neuroimaging Initiative 3: Continued innovation for clinical trial improvement. Alzheimer's Dement. 2017, 13, 561-571. [CrossRef] [PubMed]

11. Biagioni, M.C.; Galvin, J.E. Using biomarkers to improve detection of Alzheimer's disease. Neurodegener. Dis. Manag. 2011, 1, 127-139. [CrossRef] [PubMed]

12. Scarano, S.; Lisi, S.; Ravelet, C.; Peyrin, E.; Minunni, M. Detecting Alzheimer's disease biomarkers: From antibodies to new bio-mimetic receptors and their application to established and emerging bioanalytical platforms-A critical review. Anal. Chim. Acta 2016, 940, 21-37. [CrossRef] [PubMed]

13. Lane, C.A.; Hardy, J.; Schott, J.M. Alzheimer's disease. Eur. J. Neurol. 2017. [CrossRef] [PubMed]

14. Heneka, M.T.; Carson, M.J.; Khoury, J.E.; Landreth, G.E.; Brosseron, F.; Feinstein, D.L.; Jacobs, A.H.; Wyss-Coray, T.; Vitorica, J.; Ransohoff, R.M.; et al. Neuroinflammation in Alzheimer's disease. Lancet Neurol. 2015, 14, 388-405. [CrossRef]

15. Banks, W.A. Developing drugs that can cross the blood-brain barrier: Applications to Alzheimer's disease. BMC Neurosci. 2008, 9, S2. [CrossRef] [PubMed]

16. Simon, R.J.; Kania, R.S.; Zuckermann, R.N.; Huebner, V.D.; Jewell, D.A.; Banville, S.; Ng, S.; Wang, L.; Rosenberg, S.; et al. Peptoids: A modular approach to drug discovery. Proc. Natl. Acad. Sci. USA 1992, 89, 9367-9371. [CrossRef] [PubMed]

17. Guarna, A.; Trabocchi, A. Peptidomimetics in Organic and Medicinal Chemistry: The Art of Transforming Peptides in Drugs; John Wiley \& Sons: Chichester, UK, 2014; pp. 123-135. ISBN 9781119950608.

18. Udugamasooriya, G. Peptoids: An Emerging Class of Peptidomimetics for Cancer Therapy and Diagnostics. J. Biomol. Res. Ther. 2014, 3. [CrossRef]

19. Horne, W.S. Peptide and peptoid foldamers in medicinal chemistry. Expert Opin. Drug Discov. 2011, 6, 1247-1262. [CrossRef] [PubMed]

20. Mándity, I.M.; Fülöp, F. An overview of peptide and peptoid foldamers in medicinal chemistry. Expert Opin. Drug Discov. 2015, 10, 1163-1177. [CrossRef] [PubMed] 
21. Zuckermann, R.N.; Kerr, J.M.; Kent, S.B.H.; Moos, W.H. Efficient method for the preparation of peptoids [oligo(N-substituted glycines)] by submonomer solid-phase synthesis. J. Am. Chem. Soc. 1992, 114, 10646-10647. [CrossRef]

22. Olivos, H.J.; Alluri, P.G.; Reddy, M.M.; Salony, D.; Kodadek, T. Microwave-Assisted Solid-Phase Synthesis of Peptoids. Org. Lett. 2002, 4, 4057-4059. [CrossRef] [PubMed]

23. Roy, O.; Caumes, C.; Esvan, Y.; Didierjean, C.; Faure, S.; Taillefumier, C. The tert-Butyl Side Chain: A Powerful Means to Lock Peptoid Amide Bonds in the Cis Conformation. Org. Lett. 2013, 15, 2246-2249. [CrossRef] [PubMed]

24. Astle, J.M.; Udugamasooriya, D.G.; Smallshaw, J.E.; Kodadek, T. A VEGFR2 Antagonist and Other Peptoids Evade Immune Recognition. Int. J. Pept. Res. Ther. 2008, 14, 223-227. [CrossRef]

25. Zuckermann, R.N.; Kodadek, T. Peptoids as potential therapeutics. Curr. Opin. Mol. Ther. 2009, 11, $299-307$. [PubMed]

26. Kwon, Y.-U.; Kodadek, T. Quantitative Evaluation of the Relative Cell Permeability of Peptoids and Peptides. J. Am. Chem. Soc. 2007, 129, 1508-1509. [CrossRef] [PubMed]

27. Schwochert, J.; Turner, R.; Thang, M.; Berkeley, R.F.; Ponkey, A.R.; Rodriguez, K.M.; Leung, S.S.F.; Khunte, B.; Goetz, G.; Limberakis, C.; et al. Peptide to Peptoid Substitutions Increase Cell Permeability in Cyclic Hexapeptides. Org. Lett. 2015, 17, 2928-2931. [CrossRef] [PubMed]

28. Furukawa, A.; Townsend, C.E.; Schwochert, J.; Pye, C.R.; Bednarek, M.A.; Lokey, R.S. Passive Membrane Permeability in Cyclic Peptomer Scaffolds Is Robust to Extensive Variation in Side Chain Functionality and Backbone Geometry. J. Med. Chem. 2016, 59, 9503-9512. [CrossRef] [PubMed]

29. Tan, N.C.; Yu, P.; Kwon, Y.-U.; Kodadek, T. High-throughput evaluation of relative cell permeability between peptoids and peptides. Bioorg. Med. Chem. 2008, 16, 5853-5861. [CrossRef] [PubMed]

30. Mandel, S.; Amit, T.; Bar-Am, O.; Youdim, M.B.H. Iron dysregulation in Alzheimer's disease: Multimodal brain permeable iron chelating drugs, possessing neuroprotective-neurorescue and amyloid precursor protein-processing regulatory activities as therapeutic agents. Prog. Neurobiol. 2007, 82, 348-360. [CrossRef] [PubMed]

31. Vanderstichele, H.; Kodadek, T. Roadblocks for integration of novel biomarker concepts into clinical routine: The peptoid approach. Alzheimers Res. Ther. 2014, 6, 23. [CrossRef] [PubMed]

32. Glenner, G.G.; Wong, C.W. Alzheimer's disease: Initial report of the purification and characterization of a novel cerebrovascular amyloid protein. Biochem. Biophys. Res. Commun. 1984, 120, 885-890. [CrossRef]

33. Glenner, G.G.; Wong, C.W. Alzheimer's disease and Down's syndrome: Sharing of a unique cerebrovascular amyloid fibril protein. Biochem. Biophys. Res. Commun. 1984, 122, 1131-1135. [CrossRef]

34. Selkoe, D.J.; Hardy, J. The amyloid hypothesis of Alzheimer's disease at 25 years. EMBO Mol. Med. 2016, 8, 595-608. [CrossRef] [PubMed]

35. Jin, M.; Shepardson, N.; Yang, T.; Chen, G.; Walsh, D.; Selkoe, D.J. Soluble amyloid -protein dimers isolated from Alzheimer cortex directly induce Tau hyperphosphorylation and neuritic degeneration. Proc. Natl. Acad. Sci. USA 2011, 108, 5819-5824. [CrossRef] [PubMed]

36. Haass, C.; Selkoe, D.J. Soluble protein oligomers in neurodegeneration: Lessons from the Alzheimer's amyloid beta-peptide. Nat. Rev. Mol. Cell Biol. 2007, 8, 101-112. [CrossRef] [PubMed]

37. Funke, S.A.; Willbold, D. Peptides for therapy and diagnosis of Alzheimer's disease. Curr. Pharm. Des. 2012, 18, 755-767. [CrossRef] [PubMed]

38. Adessi, C.; Frossard, M.-J.; Boissard, C.; Fraga, S.; Bieler, S.; Ruckle, T.; Vilbois, F.; Robinson, S.M.; Mutter, M.; Banks, W.A.; et al. Pharmacological profiles of peptide drug candidates for the treatment of Alzheimer's disease. J. Biol. Chem. 2003, 278, 13905-13911. [CrossRef] [PubMed]

39. Penninkilampi, R.; Brothers, H.M.; Eslick, G.D. Safety and Efficacy of Anti-Amyloid- $\beta$ Immunotherapy in Alzheimer's Disease: A Systematic Review and Meta-Analysis. J. Neuroimmune Pharmacol. 2017, 12, $194-203$. [CrossRef] [PubMed]

40. Zhao, Z.; Zhu, L.; Li, H.; Cheng, P.; Peng, J.; Yin, Y.; Yang, Y.; Wang, C.; Hu, Z.; Yang, Y. Antiamyloidogenic

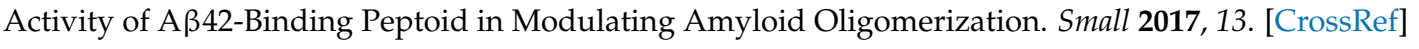

41. Bezprozvanny, I.; Luo, Y.; Chen, X.; Kodadek, T. Peptoid Compositions for the Treatment of Alzheimer's Disease and Polyglutamine Expansion Disorder. WO 2,013,043,669 A1, 28 March 2013. 
42. Luo, Y.; Vali, S.; Sun, S.; Chen, X.; Liang, X.; Drozhzhina, T.; Popugaeva, E.; Bezprozvanny, I. A $\beta 42$-binding peptoids as amyloid aggregation inhibitors and detection ligands. ACS Chem. Neurosci. 2013, 4, 952-962. [CrossRef] [PubMed]

43. Servoss, S.; Moss, M. Peptoids and Methods for Treating Alzheimer's Disease. U.S. Patent 20,130,102,539, 25 April 2013.

44. Turner, J.P.; Lutz-Rechtin, T.; Moore, K.A.; Rogers, L.; Bhave, O.; Moss, M.A.; Servoss, S.L. Rationally Designed Peptoids Modulate Aggregation of Amyloid-Beta 40. ACS Chem. Neurosci. 2014, 5, 552-558. [CrossRef] [PubMed]

45. Tjernberg, L.O.; Näslund, J.; Lindqvist, F.; Johansson, J.; Karlström, A.R.; Thyberg, J.; Terenius, L.; Nordstedt, C. Arrest of -Amyloid Fibril Formation by a Pentapeptide Ligand. J. Biol. Chem. 1996, 271, 8545-8548. [CrossRef] [PubMed]

46. Tjernberg, L.O.; Lilliehöök, C.; Callaway, D.J.; Näslund, J.; Hahne, S.; Thyberg, J.; Terenius, L.; Nordstedt, C. Controlling amyloid beta-peptide fibril formation with protease-stable ligands. J. Biol. Chem. 1997, 272, 12601-12605. [CrossRef] [PubMed]

47. Turner, J.P.; Chastain, S.E.; Park, D.; Moss, M.A.; Servoss, S.L. Modulating amyloid- $\beta$ aggregation: The effects of peptoid side chain placement and chirality. Bioorg. Med. Chem. 2017, 25, 20-26. [CrossRef] [PubMed]

48. Rankovic, Z. CNS Physicochemical Property Space Shaped by a Diverse Set of Molecules with Experimentally Determined Exposure in the Mouse Brain: Miniperspective. J. Med. Chem. 2017, 60, 5943-5954. [CrossRef] [PubMed]

49. Sadowski, M.J.; Kirshenbaum, K. Peptoid and Synthetic Oligomers, Pharmaceutical Compositions and Methods of Using Same. U.S. Patent 9,364,449 B2, 14 June 2016.

50. Liu, S.; Park, S.; Allington, G.; Prelli, F.; Sun, Y.; Martá-Ariza, M.; Scholtzova, H.; Biswas, G.; Brown, B.; Verghese, P.B.; et al. Targeting Apolipoprotein E/Amyloid $\beta$ Binding by Peptoid CPO_A $\beta 17-21$ P Ameliorates Alzheimer's Disease Related Pathology and Cognitive Decline. Sci. Rep. 2017, 7. [CrossRef] [PubMed]

51. Yan, Y.; Wang, C. A $\beta 42$ is more rigid than $A b e t a 40$ at the $C$ terminus: Implications for $A \beta$ aggregation and toxicity. J. Mol. Biol. 2006, 364, 853-862. [CrossRef] [PubMed]

52. Lipinski, C.A.; Lombardo, F.; Dominy, B.W.; Feeney, P.J. Experimental and computational approaches to estimate solubility and permeability in drug discovery and development settings. Adv. Drug Deliv. Rev. 1997, 23, 3-25, reprinted in Adv. Drug Deliv. Rev. 2001, 46, 3-26. [CrossRef]

53. Zabrodski, T.; Baskin, M.; Kaniraj, P.; Maayan, G. Click To Bind: Microwave-Assisted Solid-Phase Synthesis of Peptoids Incorporating Pyridine-Triazole Ligands and Their Copper(II) Complexes. Synlett 2015, 26, 461-466. [CrossRef]

54. Maayan, G.; Yoo, B.; Kirshenbaum, K. Heterocyclic amines for the construction of peptoid oligomers bearing multi-dentate ligands. Tetrahedron Lett. 2008, 49, 335-338. [CrossRef] [PubMed]

55. Baskin, M.; Maayan, G. Water-soluble chiral metallopeptoids: Water-Soluble Chiral Metallopeptoids. Biopolymers 2015, 104, 577-584. [CrossRef] [PubMed]

56. Maayan, G.; Ward, M.D.; Kirshenbaum, K. Metallopeptoids. Chem. Commun. 2009, 56-58. [CrossRef] [PubMed]

57. Zborovsky, L.; Smolyakova, A.; Baskin, M.; Maayan, G. A Pure Polyproline Type I-like Peptoid Helix by Metal Coordination. Chem. A Eur. J. 2017. [CrossRef] [PubMed]

58. Baskin, M.; Maayan, G. A rationally designed metal-binding helical peptoid for selective recognition processes. Chem. Sci. 2016, 7, 2809-2820. [CrossRef] [PubMed]

59. Savithri, A.; Thulasi, S.; Varma, R.L. Narrow-Rim Functionalization of Calix[4]arene through Ugi-4CR: Synthesis of a Series of Calix[4]arene Peptoids. J. Org. Chem. 2014, 79, 1683-1689. [CrossRef] [PubMed]

60. Lee, B.-C.; Chu, T.K.; Dill, K.A.; Zuckermann, R.N. Biomimetic Nanostructures: Creating a High-Affinity Zinc-Binding Site in a Folded Nonbiological Polymer. J. Am. Chem. Soc. 2008, 130, 8847-8855. [CrossRef] [PubMed]

61. Elchinger, P.-H.; Delattre, C.; Faure, S.; Roy, O.; Badel, S.; Bernardi, T.; Michaud, P.; Taillefumier, C. Antioxidant Activities of Peptoid-Grafted Chitosan Films. Appl. Biochem. Biotechnol. 2017, 181, 283-293. [CrossRef] [PubMed]

62. Nalband, D.M.; Warner, B.P.; Zahler, N.H.; Kirshenbaum, K. Rapid identification of metal-binding peptoid oligomers by on-resin X-ray fluorescence screening. Biopolymers 2014, 102, 407-415. [CrossRef] [PubMed] 
63. Pirrung, M.C.; Park, K. Discovery of selective metal-binding peptoids using 19F encoded combinatorial libraries. Bioorg. Med. Chem. Lett. 2000, 10, 2115-2118. [CrossRef]

64. Pirrung, M.C.; Park, K.; Tumey, L.N. ${ }^{19}$ F-encoded combinatorial libraries: Discovery of selective metal binding and catalytic peptoids. J. Comb. Chem. 2002, 4, 329-344. [CrossRef] [PubMed]

65. Xu, H.H.K.; Simon, C.G. Fast setting calcium phosphate-chitosan scaffold: Mechanical properties and biocompatibility. Biomaterials 2005, 26, 1337-1348. [CrossRef] [PubMed]

66. Zhang, Y.; Ni, M.; Zhang, M.; Ratner, B. Calcium Phosphate-Chitosan Composite Scaffolds for Bone Tissue Engineering. Tissue Eng. 2003, 9, 337-345. [CrossRef] [PubMed]

67. Prior, M.; Chiruta, C.; Currais, A.; Goldberg, J.; Ramsey, J.; Dargusch, R.; Maher, P.A.; Schubert, D. Back to the Future with Phenotypic Screening. ACS Chem. Neurosci. 2014, 5, 503-513. [CrossRef] [PubMed]

68. Cummings, J.; Lee, G.; Mortsdorf, T.; Ritter, A.; Zhong, K. Alzheimer's disease drug development pipeline: 2017. Alzheimer's Dement. Transl. Res. Clin. Interv. 2017, 3, 367-384. [CrossRef] [PubMed]

69. Zuckermann, R.N. Peptoid origins. Biopolymers 2011, 96, 545-555. [CrossRef] [PubMed]

70. Nielsen, P.E. (Ed.) Pseudo-Peptides in Drug Discovery; Wiley-VCH: Weinheim, Germany, 2004; ISBN 978-3-527-30633-6.

71. Hecht, S.; Huc, I. Foldamers: Structure, Properties, and Applications; Wiley InterScience (Online service); Wiley-VCH: Weinheim, Germany, 2007; ISBN 978-3-527-61147-8.

(c) 2018 by the author. Licensee MDPI, Basel, Switzerland. This article is an open access article distributed under the terms and conditions of the Creative Commons Attribution (CC BY) license (http://creativecommons.org/licenses/by/4.0/). 